Santi Pratiwi Tri Utami \& Ahmad Syaifudin: Penerapan Teknik Koreksi

\title{
PENERAPAN TEKNIK KOREKSI TIDAK LANGSUNG UNTUK MEMINIMALKAN KESALAHAN BERBAHASA DALAM PENYUSUNAN KARYA ILMIAH
}

\author{
Santi Pratiwi Tri Utami \\ Ahmad Syaifudin \\ FBS Universitas Negeri Semarang \\ Korespondensi: Jl. Sekaran, Gunungpati, Semarang, Jawa Tengah 50229 \\ Laman: http://fbs.unnes.ac.id
}

\begin{abstract}
Abstrak
Sebagian besar mahasiswa masih mengeluhkan kesulitan mengorganisasikan isi dan menerapkan kaidah tulis ilmiah dalam tugas penyusunan karya ilmiah sehingga banyak kesalahan berbahasa yang timbul. Penelitian ini bertujuan untuk meminimalkan kesalahan berbahasa dengan teknik koreksi tidak langsung. Penelitian Tindakan Kelas ini dilaksanakan dalam dua siklus. Hasil penelitian menunjukkan adanya penurunan tingkat kesalahan berbahasa baik pada tindakan prasiklus, siklus I, dan siklus II. Secara keseluruhan penurunan rata-rata sebesar 25,06\%. Jumlah rata-rata kesalahan berbahasa pada tahap prasiklus sebesar 24\%, pada siklus II jumlah rata-rata kesalahan berbahasa menurun menjadi 13,75\%. Selain hasil tersebut, terdapat persepsi dan kesan positif dari mahasiswa pada perkuliahan MKU bahasa Indonesia.
\end{abstract}

Kata-kata kunci: teknik koreksi tidak langsung, kesalahan berbahasa, karya ilmiah

\begin{abstract}
Most students still complain about difficulties in organizing content and applying the rules of scientific writing in preparing scientific papers as they commit so many errors. This study aims to minimize language errors by indirect correction techniques. This Classroom Action Research was conducted in two cycles. The results show a decrease in the error rate on language use both in the actions of pre-cycle, the first cycle and the second cycle. In total, there was an average decrease of $25.06 \%$. The number of average errors on language use in the stage of pre-cycle was $24 \%$, the number of average errors on language use decreased to $13,75 \%$ in cycle II. In addition to those results, there was a positive perception and impression in the students towards the General Subject Course of Indonesian Language.
\end{abstract}

Keywords: indirect correction techniques, errors in language use, scientific writing

\section{PENDAHULUAN}

Karya ilmiah merupakan salah satu sarana penyebaran ilmu pengetahuan dan teknologi (Iptek). Dalam dunia akademik, khususnya perguruan tinggi, menulis karya ilmiah merupakan sebuah kewajiban. Saat menulis karya ilmiah, sebagian besar mahasiswa mengeluhkan kesulitan mengorganisasikan isi dan menerapkan kaidah-kaidah penulisan karya ilmiah. Hal ini dapat dipahami karena dalam menulis sebuah karya ilmiah memang tidak hanya dituntut kemampuan untuk berpikir logis namun juga harus mampu berpikir secara 
runtut. Tuntutan kaidah-kaidah penulisan yang baku dalam karya ilmiah, seperti tata letak dan tata tulis ternyata juga menjadi faktor penghambat.

Menurut Purwadi (2000) ada dua pandangan yang bertolak belakang mengenai kesalahan berbahasa, yakni pandangan dari sudut dosen dan pandangan dari sudut mahasiswa. Dari sudut pandang dosen kesalahan berbahasa itu adalah suatu aib atau cacat cela bagi pengajaran bahasa. Kesalahan berbahasa yang dibuat oleh mahasiswa menandakan bahwa pengajaran bahasa tidak berhasil atau gagal. Oleh karena itu, kesalahan berbahasa harus dihindari agar pengajaran bahasa berhasil. Dari sudut pandang mahasiswa, kesalahan berbahasa merupakan bagian yang integral dari proses belajar mengajar bahasa. Kesalahan berbahasa dapat diminimalkan bahkan dihilangkan dengan menata komponen proses belajar mengajar bahasa secara lebih sempurna.

Apabila berpedoman pada imbauan "Gunakan bahasa Indonesia dengan baik dan benar" maka ada dua ukuran dalam mendefinisikan kesalahan berbahasa (Tarigan dan Sulistyaningsih, 1996: 29). Ukuran pertama berkaitan dengan faktorfaktor penentu dalam berkomunikasi. Ukuran kedua berkaitan dengan aturan kebahasaan yang dikenal dengan istilah tata bahasa. Bahasa Indonesia yang baik dan benar adalah bahasa Indonesia yang sesuai dengan faktor-faktor penentu berkomunikasi dan benar dalam penerapan aturan kebahasaannya. Penggunaan bahasa yang tidak sesuai dengan faktor-faktor penentu komunikasi bukanlah bahasa Indonesia yang baik. Bahasa Indonesia yang menyimpang dari kaidah bahasa yang jelas pula bukan bahasa Indonesia yang benar. Kesimpulannya, kesalahan berbahasa adalah penggunaan bahasa, secara lisan maupun tertulis, yang menyimpang dari faktor-faktor penentu berkomunikasi dan kaidah bahasa.
Keraf (2004) menyatakan bahwa "ada aspek-aspek penting yang menjadi fokus dalam berbahasa tulis. Aspek-aspek tersebut ialah memerantikan ejaan, pemilihan kata atau diksi, penyusunan kalimat efektif, dan pengembangan paragraf". Keempat aspek kebahasaan di atas merupakan satu kesatuan yang merupakan kaidah kebahasaan dalam penulisan karya ilmiah. Penelitian ini merujuk pada paparan teori keempat aspek kebahasaan di atas yang digunakan sebagai dasar untuk mengoreksi karya ilmiah mahasiswa dengan teknik koreksi tidak langsung.

Koreksi kesalahan berbahasa (KKB) dapat digunakan baik untuk kesalahan berbahasa lisan maupun kesalahan berbahasa tulis. Menurut Walz (dalam Tarigan dan Sulistyaningsih, 1996) prosedur koreksi kesalahan dapat diklasifikasikan dalam tiga kategori, yaitu koreksi diri sendiri dengan bantuan dosen, koreksi sesama mahasiswa, dan koreksi dosen. Ketiga koreksi tersebut digunakan untuk koreksi kesalahan dalam berbahasa lisan. Dosen dapat menggunakan ketiga kategori tersebut setelah mempertimbangkan berat tidaknya kesalahan yang dilakukan oleh mahasiswa. Menurut Tarigan dan Sulistyaningsih (1996) untuk mengatasi kesalahan berbahasa tulis, dapat digunakan dua macam teknik, yaitu: teknik koreksi langsung (direct correction techniques) dan teknik koreksi tidak langsung (indirect correction techniques). Dosen menggunakan teknik koreksi langsung dengan pertimbangan mahasiswa kurang mampu dalam mengoreksi kesalahan berbahasanya. Dengan demikian, dosen memperbaiki kesalahan mahasiswa langsung pada tulisan yang salah. Selain itu, dosen dapat juga menggunakan teknik koreksi tidak langsung dengan pertimbangan bahwa dengan teknik ini mahasiswa diberi kesempatan menginterpretasikan kode-kode (simbol) yang digunakan oleh dosen pada waktu menandai kesalahan-kesalahan dari karya 
ilmiah mahasiswa. Mereka memperbaiki kesalahan sendiri kemudian menuliskan kembali karya ilmiah tersebut.

Karangan ilmiah adalah "karangan ilmu pengetahuan yang menyajikan fakta umum yang dapat dibuktikan kebenarannya, disajikan dengan metodologi penulisan yang baik dan benar, serta menggunakan bahasa ragam ilmiah". Arifin (2008) menegaskan ciri khusus karya ilmiah adalah "ditulis secara jujur dan akurat berdasarkan kebenaran tanpa mengingat akibatnya". Kebenaran dalam karya ilmiah tersebut adalah kebenaran yang objektif-positif, sesuai dengan data dan fakta di lapangan, dan bukan kebenaran yang normatif.

Karya ilmiah yang disajikan dengan menggunakan format ilmiah berdasarkan fungsinya dapat dikelompokkan menjadi dua macam, yakni karya ilmiah akademis dan karya ilmiah profesional. Karya ilmiah akademis ditulis untuk kepentingan akademis, ditulis oleh siswa atau mahasiswa di bawah bimbingan orang yang lebih profesional, tidak dipublikasikan, memerlukan proses pengujian, ditulis oleh perseorangan atau kelompok, dan lebih menekankan proses daripada hasil. Bentuk karya ilmiah akademis misalnya paper atau makalah, artikel, skripsi, tesis, dan disertasi.

Karya ilmiah profesional ditulis sebagai sarana pengembangan profesi bagi kaum profesional. Karya ilmiah profesional ditulis tanpa memerlukan bimbingan namun tetap memerlukan penilaian, umumnya diterbitkan, disusun oleh individu atau kelompok, dan lebih menekankan hasil daripada proses. Bentuk karya ilmiah profesional misalnya buku, makalah, kertas kerja, artikel ilmiah, dan laporan penelitian.

Mengingat pentingnya karya ilmiah dalam berbagai kegiatan akademik baik bagi individu maupun bagi institusi maka harus segera dicari solusi untuk mengatasi permasalahan tersebut. Apabila dicermati, selama ini proses pembelajaran menulis karya ilmiah hanya berupa penyampaian materi, pemberian tugas, dan penilaian terhadap karya ilmiah. Dosen perlu berinovasi dalam proses pembelajaran sehingga mampu memberi solusi terhadap permasalahan tersebut. Salah satu hal yang dilakukan dosen ialah dengan mencermati hasil karya ilmiah mahasiswa, kemudian memberikan balikan berupa hasil koreksi tidak langsung. Selain menuntut mahasiswa untuk mencermati dan menguasai kaidah kebahasaan, hasil koreksi tidak langsung juga dapat memberi kesempatan pada mahasiswa untuk merevisi karya ilmiah yang disusun sehingga dapat meminimalkan kesalahan berbahasa yang ada.

Berdasarkan pengalaman peneliti ketika mengajar mata kuliah umum bahasa Indonesia, khususnya pada materi menulis karya ilmiah, sebagian besar mahasiswa menyatakan bahwa menyusun karya ilmiah itu rumit dan susah. Hal tersebut menyebabkan tidak banyak mahasiswa yang aktif menulis karya ilmiah. Mereka menulis karya ilmiah hanya ketika ada tugas dari dosen dalam mata kuliah tertentu atau hanya untuk memenuhi kewajiban sebagai prasyarat kelulusan.

Apabila dicermati, selama ini proses pembelajaran menulis karya ilmiah hanya berupa penyampaian materi, pemberian tugas, dan penilaian terhadap karya ilmiah. Dosen langsung memberikan penilaian tanpa memberikan balikan kepada mahasiswa terhadap karya ilmiah yang sudah disusun sehingga apabila terdapat kesalahan berbahasa pun, mahasiswa tidak mengetahui apalagi mendapatkan kejelasan tentang kaidah kebahasaan yang benar berkaitan dengan kesalahan berbahasa tersebut.

Berdasarkan penjelasan tersebut, penelitian ini mencoba memberikan alternatif solusi dalam permasalahan pembelajaran menulis karya ilmiah dengan menggunakan teknik koreksi tidak langsung untuk meminimalkan kesalahan berbahasa dalam penyusunan karya ilmiah 
khususnya bagi mahasiswa nonjurusan bahasa.

\section{METODE}

Penelitian ini menggunakan desain Penelitian Tindakan Kelas dengan pertimbangan memberikan alternatif teknik pembelajaran untuk meminimalkan kesalahan berbahasa dalam penyusunan karya ilmiah bagi mahasiswa nonjurusan bahasa. Penelitian tindakan kelas ini dilakukan dalam dua siklus.

Untuk mengetahui kemampuan siswa sebelum diberikan tindakan, terlebih dahulu diberikan tes awal sebelum siklus I. Siklus I bertujuan untuk mengetahui kemampuan berbahasa pada penyusunan karya ilmiah dalam tindakan awal penelitian. Siklus ini sekaligus dipakai sebagai refleksi untuk penyusunan karya ilmiah siklus II, sedangkan siklus II bertujuan untuk mengetahui kemampuan berbahasa dalam penyusunan karya ilmiah setelah dilakukan perbaikan dan inovasi teknik pembelajaran terhadap pelaksanaan proses belajar mengajar yang didasarkan pada refleksi siklus I.

Subjek penelitian ini ialah kesalahan berbahasa dalam penyusunan karya ilmiah berupa tugas menyusun artikel konseptual dan hasil kuesioner yang telah diisi oleh sumber data. Dalam penelitian ini, penetapan sumber data didasarkan dari latar belakang jurusannya, yaitu yang berasal dari nonjurusan bahasa, karena peserta MKU bahasa Indonesia ada yang berasal dari jurusan bahasa Jawa dan bahasa asing. Penelitian ini dilangsungkan pada semester genap tahun akademik 2011. Sumber data berjumlah 40 mahasiswa dalam rombongan belajar (rombel) 39 berdasarkan jurusan asal mahasiswa.

Variabel dalam penelitian ini ada dua macam yaitu variabel kesalahan berbahasa dan variabel teknik koreksi tidak langsung. Variabel kesalahan berbahasa, dianalisis dengan aspek atau kaidah kebahasaan yaitu ejaan, diksi atau pilihan kata, kalimat efektif, dan pengembangan paragraf. Variabel teknik koreksi tidak langsung, pada dasarnya merupakan teknik koreksi kesalahan berbahasa tulis yang dilakukan dengan hanya memberikan simbol-simbol tertulis yang dilekatkan pada kesalahan berbahasa yang ditemukan saat proses pengoreksian.

Penelitian tindakan kelas ini menggunakan instrumen bentuk tes dan nontes. Tes yang dimaksud dalam penelitian ini adalah tes tertulis berupa tugas menulis karya ilmiah berbentuk artikel konseptual. Instrumen nontes yang digunakan berupa kuesioner untuk mengetahui persepsi dan kesan sumber data terhadap penerapan teknik koreksi tidak langsung.

Data dalam penelitian diperoleh dengan memberikan tugas menulis karya ilmiah berupa artikel konseptual. Tes dilakukan sebanyak dua kali yaitu pada tes siklus I dan tes pada siklus II. Selain itu, data juga dikumpulkan melalui pembagian kuesioner kepada sumber data di akhir pembelajaran untuk mengetahui persepsi dan kesan terhadap penerapan teknik koreksi tidak langsung. Data dari instrumen nontes berupa kuesioner dianalisis secara kualitatif dengan cara merekap dan mendeskripsikan data. Setelah itu akan dapat disimpulkan bagaimana persepsi dan kesan mahasiswa terhadap penerapan teknik koreksi tidak langsung.

Jenis karya ilmiah yang digunakan sebagai data dalam penelitian ini adalah artikel konseptual. Karya ilmiah ini dapat digolongkan dalam karya ilmiah akademik maupun karya ilmiah profesional. Namun, artikel konseptual yang digunakan ialah yang termasuk dalam golongan karya ilmiah akademik karena disusun oleh mahasiswa sebagai tugas dalam mata kuliah. Secara lebih jelas, artikel konseptual ialah hasil pemikiran penulis atas suatu permasalahan, yang dituangkan dalam bentuk tulisan. Dalam upaya untuk menghasilkan artikel jenis ini penulis 
terlebih dahulu mengkaji sumber-sumber yang relevan dengan permasalahannya, baik yang sejalan maupun yang bertentangan dengan apa yang dipikirkan oleh penulis. Sumber-sumber yang dianjurkan untuk dirujuk dalam rangka menghasilkan artikel konseptual adalah juga artikel-artikel konseptual yang relevan, hasil-hasil penelitian terdahulu, di samping teori-teori yang dapat digali dari buku-buku teks.

Bagian paling vital dari artikel konseptual adalah pendapat atau pendirian penulis tentang hal yang dibahas, yang dikembangkan dari analisis terhadap pikiran-pikiran mengenai masalah yang sama yang telah dipublikasikan sebelumnya. Jadi, artikel konseptual bukanlah sekedar kolase cuplikan-cuplikan dari sejumlah artikel, apalagi pemindahan tulisan dari sejumlah sumber, tetapi hasil pemikiran analitis dan kritis penulisnya.

\section{HASIL DAN PEMBAHASAN}

Sebelum tindakan siklus I dilaksanakan, terlebih dahulu diadakan apersepsi mata kuliah umum bahasa Indonesia kompetensi dasar analisis kesalahan berbahasa tulis. Hal ini dilakukan untuk mengetahui tingkat kemampuan mahasiswa dalam penguasaan kompetensi kebahasaan tulis. Dalam hal ini, dosen menuliskan beberapa kata dan kalimat yang rancu di whiteboard, kemudian dosen meminta beberapa mahasiswa secara acak untuk menganalisis kata dan kalimat tersebut. Jika dirasa belum betul, maka mahasiswa lain dipersilakan untuk menganalisis hingga dirasa cukup mendekati hasil analisis yang logis dan tepat.

Setelah dilaksanakan apersepsi tersebut, ternyata masih banyak mahasiswa yang belum dapat menganalisis ejaan, diksi, dan kalimat yang tepat dan efektif. Untuk mengetahui tingkat penguasaan kebahasaan tulis secara keseluruhan, maka diadakan tindakan prasiklus berupa menyusun karya ilmiah jenis artikel konseptual dengan tema bebas namun memperhatikan aspek ejaan, diksi, kalimat efektif, dan pengembangan paragraf.

Berdasarkan hasil rata-rata setiap aspek pada tahap prasiklus, yaitu rata-rata kesalahan aspek ejaan sebanyak 19 mahasiswa dengan rata-rata persentase 46,5\%; rata-rata kesalahan aspek diksi sebanyak 14 mahasiswa dengan rata-rata persentase 35\%; rata-rata kesalahan aspek kalimat efektif sebanyak 17 mahasiswa dengan rata-rata persentase $42,5 \%$; dan rata-rata 13 mahasiswa dengan persentase $31,25 \%$ melakukan kesalahan aspek pengembangan paragraf. Simpulan yang dapat diambil dari hasil prasiklus tersebut, bahwa mahasiswa belum mampu atau belum menguasai kompetensi kebahasaan tulis. Hal ini terlihat dari banyaknya jumlah responden yang melakukan kesalahan hampir sebagian dari jumlah responden, sehingga perlu upaya untuk meminimalkan kesalahan berbahasa dalam penyusunan karya ilmiah. Adapun upaya yang dilakukan melalui proses penelitian tindakan kelas. Proses tindakan kelas tersebut direncanakan dalam 2 kali tindakan yaitu siklus I dan siklus II.

Pelaksanaan siklus I dilakukan selama dua kali perkuliahan. Pada perkuliahan pertama, peneliti menjelaskan tentang kompetensi dasar penyusunan karya ilmiah jenis artikel konseptual, yaitu konsep dan ciri artikel konseptual, serta cara menyusun artikel konseptual sekaligus menunjukkan contoh artikel konseptual yang benar, kemudian mahasiswa diberi tugas untuk menyusun artikel konseptual. Pada perkuliahan kedua, peneliti menjelaskan tentang teknik koreksi bahasa dalam penyusunan karya ilmiah, yaitu teknik koreksi langsung dan teknik koreksi tidak langsung. Langkah selanjutnya dosen mengkoreksi tugas artikel konseptual mahasiswa dengan teknik koreksi tidak langsung.

Tindakan yang dilakukan pada siklus II yaitu memberikan penjelasan yang lebih kompleks lagi mengenai analisis kesalahan berbahasa yaitu penggunaan ejaan, pemilihan kata atau 
diksi, penyusunan kalimat efektif, dan pengembangan paragraf. Selain itu, peneliti juga membahas kesalahankesalahan berbahasa yang telah dilakukan mahasiswa yang telah dikoreksi dengan menggunakan teknik koreksi tidak langsung, sehingga mahasiswa tahu analisis dari kesalahan tersebut dan tidak mengulangi kesalahan tersebut serta diharapkan dapat meminimalisasi kesalahan berbahasa dalam penyusunan karya ilmiah berikutnya. Dari tindakan pada siklus II diperoleh persentase tingkat kesalahan yang semakin menurun apabila dibandingkan siklus I, data lebih jelas dapat dilihat pada tabel berikut.

Tabel 1. Tingkat Peminimalan Kesalahan Berbahasa dalam Penyusunan Karya Ilmiah

\begin{tabular}{llccccc}
\hline No & $\begin{array}{c}\text { Aspek-Aspek } \\
\text { Kebahasaan Tulis }\end{array}$ & $\begin{array}{c}\text { Prasiklus } \\
(\boldsymbol{\%})\end{array}$ & $\begin{array}{c}\text { Siklus I } \\
(\boldsymbol{\%})\end{array}$ & $\begin{array}{c}\text { Siklus II } \\
\mathbf{( \% )}\end{array}$ & $\begin{array}{c}\text { Tingkat } \\
\text { Peminimalan } \\
(\boldsymbol{\%})\end{array}$ & $\begin{array}{c}\text { Jumlah } \\
\text { Penurunan } \\
\text { R.S }\end{array}$ \\
\hline 1. & Ejaan & 46,5 & 36 & 21,5 & 25 & 5 \\
2. & Diksi & 35 & 21,25 & 8,75 & 26,25 & 5 \\
3. & Kalimat Efektif & 42,5 & 25 & 16 & 26,5 & 6 \\
4. & Pengembangan Paragraf & 31,25 & 13,75 & 8,75 & 22,5 & 5 \\
\hline & Jumlah & 155,25 & 96 & 55 & 100,25 & 21 \\
\hline & Rata-rata & 38,81 & 24 & 13,75 & 25,06 & \\
\hline
\end{tabular}

Keterangan: R.S= responden yang melakukan kesalahan

Kesalahan-kesalahan berbahasa pada siklus II semakin berkurang, yang semula pada rata-rata persentase prasiklus sebesar $38,81 \%$, menjadi rata-rata $24 \%$ setelah siklus I, dan setelah siklus II dilaksanakan jumlah rata-rata tingkat kesalahan menurun kembali menjadi $13,75 \%$ dan keberhasilan rata-rata tingkat peminimalan kesalahan bahasa sebesar $25,06 \%$. Dengan demikian, pada siklus II terjadi tingkat peminimalan kesalahan bahasa pada setiap aspeknya dalam penyusunan karya ilmiah berupa artikel konseptual, maka penelitian tidak dilanjutkan pada siklus berikutnya.

Hasil nontes berupa kuesioner menunjukkan bahwa sebanyak 31 mahasiswa tertarik akan penerapan teknik koreksi tidak langsung. Ini sangat berpengaruh terhadap peminimalan kesalahan berbahasa dalam penyusunan karya ilmiah. Sementara sisanya kurang tertarik dengan teknik koreksi tidak langsung. Mereka merasa kurang efektif karena harus mencermati tanda-tanda koreksi tidak langsung yang diberikan oleh dosen pada tugas mereka. Mereka lebih menyukai dan memilih teknik koreksi langsung yang menunjukkan langsung kesalahan yang mereka perbuat tanpa harus mencermati terlebih dahulu. Pada siklus II juga didapati kenyataan bahwa 34 mahasiswa menyatakan penerapan teknik koreksi tidak langsung berhasil dilakukan oleh dosen sehingga peminimalan kesalahan berbahasa dalam penyusunan karya ilmiah juga bisa diwujudkan.

Setelah dilakukan analisis data tes diperoleh kenyataan bahwa penerapan teknik koreksi tidak langsung dapat meminimalkan kesalahan berbahasa dalam penyusunan karya ilmiah mahasiswa nonjurusan bahasa. Pembahasan hasil penelitian mengacu pada pemerolehan persentase rata-rata responden yang melakukan kesalahan berbahasa dalam penyusunan karya ilmiah.

Aspek-aspek yang dianalisis dalam penguasaan kebahasaan tulis terdiri dari aspek ejaan, diksi, kalimat efektif, dan pengembangan paragraf. Aspek ejaan terdiri dari 5 subaspek yaitu pemakaian dan penulisan huruf, pemakaian dan penulisan kata, pemakaian dan penulisan tanda baca, penulisan unsur serapan, dan penulisan singkatan. Aspek diksi terdiri dari 2 subaspek yaitu ketepatan pilihan kata dan kesesuaian pilihan kata. Aspek 
kalimat efektif terdiri dari 5 subaspek yaitu kesatuan gagasan, koherensi kalimat, variasi kalimat, paralelisme, dan penalaran kalimat. Aspek pengembangan paragraf terdiri atas 2 subaspek yaitu kesatuan paragraf dan kepaduan paragraf.

Pada tahap prasiklus aspek yang paling tinggi tingkat kesalahannya yaitu aspek Ejaan sebesar $46,5 \%$, pada siklus I menurun menjadi $36 \%$ dan pada siklus II menurun lagi menjadi 21,5\%. Aspek selanjutnya aspek Kalimat Efektif, pada tahap prasiklus sebanyak $42,5 \%$, siklus I menurun menjadi $25 \%$ dan pada siklus II menjadi $16 \%$. Aspek Diksi pada prasiklus sebesar $35 \%$, siklus I menurun menjadi $21,25 \%$ kemudian pada siklus II menjadi $8,75 \%$. Aspek terakhir yaitu aspek Pengembangan Paragraf, pada prasiklus $31,25 \%$ menurun pada siklus I menjadi $13,75 \%$, dan pada siklus II menurun lagi menjadi $8,75 \%$.

Hasil tes menulis karya ilmiah pada tahap prasiklus, rata-rata persentase kesalahan berbahasa cukup tinggi dan hampir semua karya ilmiah mahasiswa mengandung kesalahan berbahasa. Hal ini terjadi karena mahasiswa belum terbiasa memperhatikan dan menguasai kompetensi kebahasaan. Mahasiswa cenderung mengabaikan aspek-aspek kebahasaan tulis, terutama aspek Ejaan yang memiliki tingkat kesalahan paling tinggi. Hal ini dikarenakan mahasiswa terlalu fokus pada esensi atau isi karya ilmiah tanpa memperhatikan aspek kebahasaan tulisnya.

Setelah menerapkan teknik koreksi tidak langsung pada siklus I, mahasiswa mulai memahami dan lebih cermat dalam menggunakan aspek kebahasaan tulis yang meliputi memerantikan ejaan, pemilihan kata atau diksi, penggunaan kalimat efektif, dan pengembangan paragraf. Hal ini terbukti dari tingkat peminimalan kesalahan berbahasa dalam penyusunan karya ilmiah mengalami penurunan responden yang melakukan kesalahan setiap aspeknya. Aspek Ejaan dan Diksi mengalami penurunan sebanyak 5 mahasiswa. Aspek Kalimat Efektif mengalami penurunan 6 mahasiswa. Adapun aspek Pengembangan Paragraf mengalami penurunan 4,5 yang dibulatkan menjadi 5 mahasiswa.

Setelah dilakukan tindakan pada siklus II, hasil tes menulis karya ilmiah berupa artikel konseptual menjadi lebih baik daripada siklus I. Hal ini dikarenakan mahasiswa sudah mulai mencermati aturan-aturan atau standar dalam kebahasaan tulis. Di samping mahasiswa sudah memahami dari segi materi, mereka juga jauh lebih paham mengaplikasian materi kebahasaan tersebut dalam penyusunan karya ilmiah setelah mengerti hakikat dan fungsi teknik koreksi tidak langsung yang diterapkan oleh dosen.

Selama perkuliahan berlangsung, mahasiswa selalu bersemangat untuk mengikutinya. Hal ini terlihat ketika dosen memberikan penjelasan tentang kegiatan perkuliahan yang akan dilaksanakan dan materi tentang penyusunan karya ilmiah berupa artikel konseptual. Hampir semua mahasiswa antusias mengikuti sehingga perkuliahan berlangsung kondusif.

Hasil kuesioner pada siklus I menunjukkan 29 mahasiswa memberikan kesan positif pada penerapan teknik koreksi tidak langsung yang diterapkan oleh dosen. Mereka mengerti maksud dari tanda-tanda koreksi yang diberikan oleh dosen pada setiap aspek kesalahan dalam tugas karya ilmiah mereka. Namun sisanya, mahasiswa masih kebingungan akan maksud dari tanda koreksi tidak langsung pada tugas mereka. Ketika dicermati pun mereka masih merasakan kebingungan karena memang dosen belum menjelaskan secara keseluruhan dan mendalam mengenai materi serta belum memaparkan hakikat dan manfaat dari penerapan teknik koreksi tidak langsung dalam penyusunan karya ilmiah.

Pada tahap siklus II semakin terlihat kesan positif yang ditunjukkan mahasiswa terhadap penerapan teknik koreksi tidak langsung oleh dosen. Hal ini dibuktikan dengan hasil kuesioner yang menunjukkan peningkatan kesan dan 
persepsi positif mahasiswa pada keterlibatannya dalam perkuliahan, pemahaman akan materi yang disampaikan oleh dosen, dan peminimalan kesalahan berbahasa yang dilakukan dalam penyusunan karya ilmiah.

\section{SIMPULAN DAN SARAN}

Berdasarkan pembahasan, penelitian tindakan kelas ini dapat disimpulkan bahwa kesalahan berbahasa dalam penyusunan karya ilmiah mahasiswa nonjurusan bahasa dengan menerapkan teknik koreksi tidak langsung terjadi penurunan pada setiap siklusnya. Sebagian besar mahasiswa telah menguasai aspek-aspek kebahasaan tulis dengan baik setelah mengikuti perkuliahan pada kompetensi dasar menulis karya ilmiah dengan menerapkan teknik koreksi tidak langsung.

Hal ini terlihat pada siklus II yang mengalami penurunan tingkat kesalahan pada tiap aspeknya. Aspek ejaan mengalami penurunan tingkat kesalahan sebanyak $25 \%$ dari $46,5 \%$ menjadi $21,5 \%$. Aspek diksi mengalami penurunan pula sebanyak 26,25\% dari 35\% menjadi $8,75 \%$. Adapun aspek kalimat efektif mengalami penurunan sebanyak $26,5 \%$ dari $42,5 \%$ menjadi $16 \%$. Terakhir, aspek pengembangan paragraf mengalami penurunan tingkat kesalahan sebanyak $22,5 \%$ dari $31,25 \%$ menjadi $8,75 \%$. Secara keseluruhan, penurunan atau peminimalan tingkat kesalahan bahasa sebanyak $100,25 \%$ dengan rata-rata penurunan sebesar $25,06 \%$.

Analisis data nontes melalui kuesioner menunjukkan bahwa mahasiswa nonjurusan bahasa memberikan persepsi dan kesan yang positif setelah diterapkan teknik koreksi tidak langsung dalam penyusunan karya ilmiah. Ini sangat berpengaruh terhadap peminimalan kesalahan berbahasa dalam penyusunan karya ilmiah. Selain itu keterlibatan mahasiswa dalam perkuliahan dan pemahaman akan materi yang disampaikan oleh dosen juga turut menunjukkan persepsi dan kesan positif terhadap penerapan teknik koreksi tidak langsung.

Sekaitan dengan hasil penelitian di atas, peneliti menyampaikan beberapa saran untuk dapat dipertimbangkan, antara lain (1) sebaiknya para dosen, khususnya dosen mata kuliah umum bahasa Indonesia mencoba menerapkan teknik koreksi tidak langsung sebagai variasi pemilihan strategi dalam meminimalisasi kesalahan berbahasa dalam penyusunan karya ilmiah; (2) mahasiswa perlu lebih cermat dalam menggunakan standar kebahasaan pada penyusunan karya ilmiah serta perlu meningkatkan penguasaan atau kompetensi kebahasaan, khususnya kebahasaan tulis.

\section{UCAPAN TERIMA KASIH}

Peneliti mengucapkan terima kasih kepada mahasiswa peserta perkuliahan MKU bahasa Indonesia dari jurusan bahasa Jawa dan bahasa asing dalam rombongan belajar (rombel) 39 semester genap tahun akademik 2011/2012 yang telah membantu menjadi sumber data dalam penelitian ini juga kepada redaksi jurnal Bahasa \& Sastra atas dipublikasikannya hasil penelitian ini.

\section{PUSTAKA RUJUKAN}

Arifin, Zaenal. 2008. Dasar-dasar Penulisan Karya Ilmiah. Jakarta: Grasindo

Keraf, Gorys. 2004. Komposisi. Ende: Nusa Indah

Purwadi. 2000. Analisis Kesalahan Berbahasa. Surakarta: UNS Press

Tarigan, Djago \& Sulistyaningsih, Lilis Siti. 1996. Analisis Kesalahan Berbahasa. Jakarta: Depdikbud

Utami, Santi Pratiwi Tri \& Syaifudin, Ahmad. 2010. Swasunting Bahasa dalam Penulisan Karya Ilmiah: Studi Kasus pada Mahasiswa Peserta Mata Kuliah Menulis Karya Ilmiah Jurusan Bahasa dan Sastra Indonesia Universitas Negeri Semarang. Laporan Penelitian 
(tidak diterbitkan). Semarang: Universitas Negeri Semarang.

Utami, Santi Pratiwi Tri \& Syaifudin, Ahmad. 2011. Penerapan Teknik Koreksi Tidak Langsung untuk Meminimalkan Kesalahan
Berbahasa dalam Penyusunan Karya Ilmiah pada Mahasiswa Nonjurusan Bahasa. Laporan Penelitian (tidak diterbitkan). Semarang: Universitas Negeri Semarang. 